Gut, 1966, 7, 159

\title{
Use of polyethylene glycol and phenol red as unabsorbed indicators for intestinal absorption studies in $\operatorname{man}^{1}$
}

\author{
HAROLD P. SCHEDL ${ }^{2}$ \\ with the technical assistance of DUANE MILLER and DONALD WHITE \\ From the Gastoenterology Research Laboratory, Department of Medicine, \\ University of Iowa College of Medicine, Iowa City, Iowa, U.S.A.
}

EDITORIAL SYNOPSIS It should be emphasized as a result of this study that phenol red is an adequate marker for a proven technique in studying intestinal absorption. Oral feeding was not studied.

Intestinal absorption may be defined operationally as the complete disappearance of a substance from the bowel lumen, and many recent studies are based on this definition (Lundh, 1958; Schanker, Tocco, Brodie, and Hogben, 1958; Borgström, Dahlquist, and Lundh, 1962). In such studies a reference substance, which, it is assumed is not absorbed, is also needed for the experimental measurement of absorption. Polyethylene glycol (P.E.G.) and phenol red are the most frequently used indicators that have been investigated (Reynell and Spray, 1956; Schanker et al., 1958; Wiggins and Dawson, 1961; Jacobson, Bondy, Broitman, and Fordtran, 1963). This paper compares data from the use of these two molecules as unabsorbed indicators.

\section{MATERIALS AND METHODS}

The indicators were used for absorption studies with a steady-state perfusion technique using a transintestinal tube (Schedl and Clifton, 1963). Twenty-three normal volunteer subjects, nine patients with non-tropical sprue, and one patient with Whipple's disease were studied. Perfusion solutions contained polyethylene glycol (P.E.G.) ( $1 \mathrm{~g} . / \mathrm{l}$.) and phenol red ( $50 \mathrm{mg}$./l.) in a modified Ringer's buffer (Schanker et al., 1958). Polyethylene glycol (from a single lot of Carbowax 4000 (Carbide and Carbon Chemical Corp., 270 Park Ave., N.Y.C.) was analysed turbidimetrically (Hydén, 1955). Phenol red (phenolsulphonphthalein, Fisher Scientific Co.) was determined in diluted alkalinized solutions by measuring optical densities at 560, 520, and $600 \mathrm{~m} \mu$ with a Beckman DU spectrophotometer (Schedl and Clifton, 1961). Polyethylene glycol and phenol red in undiluted urine were

${ }^{1}$ Supported in part by grants AM-02534 and ITI AM 5390 from the National Institute of Arthritis and Metabolic Diseases and University of Iowa funds for the Computer Center.

¿Overseas fellow, Churchill College, Cambridge, England. similarly analysed. Urine was prepared for phenol red analysis by adding $1 \mathrm{ml}$. of buffer (Schedl and Clifton, $1961)$ and one drop of concentrated $\mathrm{NaOH}$ to $10 \mathrm{ml}$. of urine.

Polyethylene glycol and phenol red concentrations were measured both in the solution perfused (initial concentration, $\mathrm{C}_{\mathrm{I}}$ ) and the samples (final concentration, $\mathrm{C}_{\mathrm{F}}$ ). The ratio $\mathrm{C}_{\mathrm{I}} / \mathrm{C}_{\mathrm{F}}$ indicates volume in the bowel lumen relative to volume infused under the steady-state conditions during collection of the sample. During net water absorption, $\mathrm{C}_{\mathrm{F}}$ of the indicator rises and the ratio falls below unity. During net secretion into the bowel, $\mathrm{C}_{\mathrm{F}}$ falls and the ratio becomes greater than one. Several different solutions were perfused in succession. There were half-hour washes with each solution before three or more successive samples were collected for analysis. About half the studies are from first, or 1 , and half from nonfirst, non-1, solutions. First and non-first solutions both contained polyethylene glycol and phenol red, but the non-first was preceded by a solution containing only polyethylene glycol. During perfusion of both together in the first solution, it may be assumed that both are equally affected by dilution from secretions in the bowel lumen. In a non-first solution, i.e., a polyethylene glycolphenol red solution perfused after a solution of polyethylene glycol, phenol red could be diluted by a preceding solution lacking it. This could occur even after the half-hour wash with the polyethylene glycol-phenol red solution that preceded collection of the sample. There would probably not be any effect on polyethylene glycol, since its initial concentration was the same in both solutions. The $\mathrm{C}_{\mathrm{F}}$ of phenol red would be decreased and the ratio $C_{\mathrm{I}} / \mathrm{C}_{\mathrm{F}}$ would be larger than for polyethylene glycol. Since three or more successive samples were analysed from the polyethylene glycol-phenol red solution, the pattern of both indicators could be determined. If dilution by the previous solution not containing phenol red appeared to be lowering the concentration of phenol red relative to polyethylene glycol, such samples were excluded, and as absorption of phenol red is more 
rapid in acid solutions, samples having a $p \mathrm{H}$ below $5 \cdot 5$ were not included.

The tabulated data are $\mathrm{C}_{\mathrm{I}} / \mathrm{C}_{\mathrm{F}}$ for the two indicators. First and non-first solutions are treated separately. Phenol red-560 (P.R. 560) is from absorbancy at $560 \mathrm{~m} \mu$; phenol red ratio corrected (P.R.C.) is $C_{\mathrm{I}} / \mathrm{C}_{\mathrm{F}}$ calculated from phenol red absorbancies measured at 520, 560, and $600 \mathrm{~m} \mu$ by the formula: corrected absorbancy $=560-$ $1 / 2(520+600)$. This corrects for linear background absorbancies in this region of the spectrum (Allen, 1950).
Urine was collected for the 18-hour period following infusions in B.B., a patient with non-tropical sprue. The individual specimens were analysed for phenol red.

\section{RESULTS}

Data in normal subjects for polyethylene glycol and phenol red are compared in Table I. Individual and population means and correlation coefficients of

TABLE I

COMPARISON OF POLYETHYLENE GLYCOL (P.E.G.) AND PHENOL RED (P.R.) IN NORMAL SUBJECTS

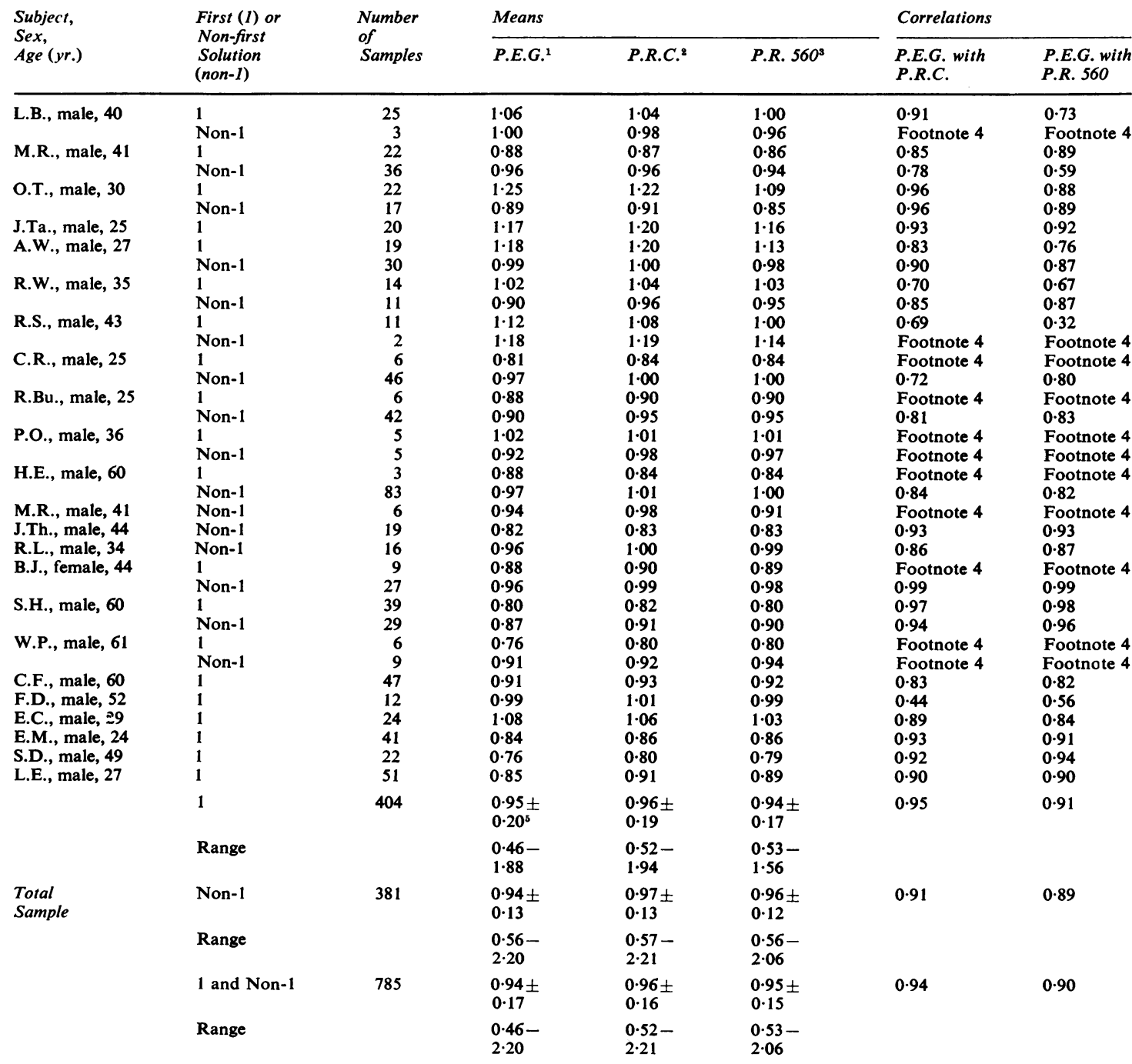

${ }^{1}$ P.E.G. is the ratio of initial to final P.E.G. concentration.

${ }^{2}$ P.R.C. is the ratio of initial to final phenol red concentration using the three wavelength correction.

3P.R. 560 is the ratio of initial to final phenol red concentration measured at $560 \mathrm{~m} \mu$.

Too few samples for statistical calculations, but included in totals. If more than 10 samples in a group, correlations are given.

${ }^{5}$ All number with \pm are means and one standard deviation of the population. 
TABLE II

COMPARISON OF POLYETHYLENE GLYCOL (P.E.G.) AND PHENOL RED (P.R.) IN STUDIES OF MALABSORPTION

\begin{tabular}{|c|c|c|c|c|c|c|c|c|}
\hline \multirow{2}{*}{$\begin{array}{l}\text { Subject, } \\
\text { Sex, } \\
\text { Age (yr.) }\end{array}$} & \multirow[t]{2}{*}{ Disease } & \multirow{2}{*}{$\begin{array}{l}\text { First }(1) \\
\text { or Non-first } \\
\text { Solution } \\
\text { (Non-1) }\end{array}$} & \multirow{2}{*}{$\begin{array}{l}\text { Number } \\
\text { of } \\
\text { Samples }\end{array}$} & \multicolumn{3}{|l|}{ Means } & \multicolumn{2}{|l|}{ Correlations } \\
\hline & & & & P.E.G. ${ }^{1}$ & P.R.C. ${ }^{2}$ & P.R. $560^{3}$ & $\begin{array}{l}\text { P.E.G. with } \\
\text { P.R.C. }\end{array}$ & $\begin{array}{l}\text { P.E.G. with } \\
\text { P.R. } 560\end{array}$ \\
\hline $\begin{array}{l}\text { G.H., male, } 60 \\
\text { A.E., female, } 60\end{array}$ & $\begin{array}{l}\text { Non-tropical } \\
\text { sprue } \\
\text { Non-tropical }\end{array}$ & 1 & 26 & $1 \cdot 07$ & 1.01 & 1.01 & 0.93 & 0.93 \\
\hline J.N., male, 69 & $\begin{array}{l}\text { sprue } \\
\text { Non-tropical }\end{array}$ & Non-1 & $\begin{array}{l}19 \\
21\end{array}$ & $\begin{array}{l}1 \cdot 14 \\
0.97\end{array}$ & $\begin{array}{l}1 \cdot 12 \\
0.98\end{array}$ & $\begin{array}{l}1 \cdot 10 \\
0 \cdot 97\end{array}$ & $\begin{array}{l}0.96 \\
0.82\end{array}$ & $\begin{array}{l}0.97 \\
0.87\end{array}$ \\
\hline H.F., male, 55 & $\begin{array}{l}\text { sprue } \\
\text { Whipple's }\end{array}$ & 1 & $\begin{array}{r}8 \\
10\end{array}$ & $\begin{array}{l}0.90 \\
1.06\end{array}$ & $\begin{array}{l}0.98 \\
1.03\end{array}$ & $\begin{array}{l}0.89 \\
1.02\end{array}$ & $\begin{array}{l}\text { Footnote } 4 \\
\text { Footnote } 4\end{array}$ & $\begin{array}{l}\text { Footnote } 4 \\
\text { Footnote } 4\end{array}$ \\
\hline R.Bo., male, 44 & $\begin{array}{l}\text { disease } \\
\text { Non-tropical }\end{array}$ & Non-1 & $\begin{array}{r}6 \\
16\end{array}$ & $\begin{array}{l}1 \cdot 25 \\
1 \cdot 15\end{array}$ & $\begin{array}{l}1 \cdot 18 \\
1 \cdot 15\end{array}$ & $\begin{array}{l}1 \cdot 11 \\
1 \cdot 12\end{array}$ & $\begin{array}{l}\text { Footnote } 4 \\
0.89\end{array}$ & $\begin{array}{l}\text { Footnote } 4 \\
0.78\end{array}$ \\
\hline R.Bo., male, 44 & $\begin{array}{l}\text { sprue }^{8} \\
\text { Non-tropical }\end{array}$ & Non-1 & $\begin{array}{r}3 \\
18\end{array}$ & $\begin{array}{l}1.04 \\
1.02\end{array}$ & $\begin{array}{l}0.95 \\
1.05\end{array}$ & $\begin{array}{l}0.95 \\
1.04\end{array}$ & $\begin{array}{l}\text { Footnote } 4 \\
0.92\end{array}$ & $\begin{array}{l}\text { Footnote } 4 \\
0.91\end{array}$ \\
\hline & sprue $^{7}$ & $\begin{array}{l}1 \\
\text { Non-1 }\end{array}$ & $\begin{array}{r}9 \\
25\end{array}$ & $\begin{array}{l}0.89 \\
0.78\end{array}$ & $\begin{array}{l}0.87 \\
0.82\end{array}$ & $\begin{array}{l}0 \cdot 86 \\
0 \cdot 81\end{array}$ & $\begin{array}{l}\text { Footnote } 4 \\
0.96\end{array}$ & $\begin{array}{l}\text { Footnote } 4 \\
0.94\end{array}$ \\
\hline $\begin{array}{l}\text { R.Bo., male, } 44 \\
\text { M.J., female, } 80\end{array}$ & $\begin{array}{l}\text { Non-tropical } \\
\text { sprue } \\
\text { Non-tropical }\end{array}$ & Non-1 & 12 & 1.05 & 1.08 & 1.07 & 0.82 & 0.78 \\
\hline A.S., female, 58 & $\begin{array}{l}\text { sprue } \\
\text { Non-tropical }\end{array}$ & Non-1 & 6 & 1.05 & 1.05 & $1 \cdot 02$ & Footnote 4 & Footnote 4 \\
\hline E.T., female, 36 & $\begin{array}{l}\text { sprue } \\
\text { Non-tropical }\end{array}$ & Non-1 & 6 & 0.96 & 0.98 & 0.98 & Footnote 4 & Footnote 4 \\
\hline B.B., female, 27 & $\begin{array}{l}\text { sprue } \\
\text { Non-tropical }\end{array}$ & Non-1 & 8 & $1 \cdot 21$ & $1 \cdot 20$ & $1 \cdot 20$ & Footnote 4 & Footnote 4 \\
\hline G.L., female, 60 & $\begin{array}{l}\text { sprue } \\
\text { Non-tropical }\end{array}$ & Non-1 & $51^{8}$ & 1.02 & $1 \cdot 18$ & 1.08 & 0.90 & 0.87 \\
\hline & sprue & $\begin{array}{l}1 \\
\text { Non-1 }\end{array}$ & $\begin{array}{l}87 \\
12\end{array}$ & $\begin{array}{l}1.06 \\
1.07\end{array}$ & $\begin{array}{l}1.08 \\
1 \cdot 14\end{array}$ & $\begin{array}{l}1.05 \\
1.04\end{array}$ & $\begin{array}{l}\mathbf{0} \cdot 81 \\
\mathbf{0} \cdot 77\end{array}$ & $\begin{array}{l}0.80 \\
0.63\end{array}$ \\
\hline & & 1 & 158 & $1.06 \pm 0.20$ & $1.06 \pm 0.21$ & $1.03 \pm 0.20$ & 0.81 & 0.82 \\
\hline & & Range & & $0.64-1.88$ & $0.66-2.38$ & $0 \cdot 66-2 \cdot 20$ & & \\
\hline Total sample & & & & & & & & \\
\hline & & $\begin{array}{l}\text { Non-1 } \\
\text { Range }\end{array}$ & 134 & $\begin{array}{l}1.00 \pm 0.19 \\
0.40-1.63\end{array}$ & $\begin{array}{l}1.02 \pm 0.18 \\
0.43-1.76\end{array}$ & $\begin{array}{l}1.00 \pm 0.18 \\
0.43-1.83\end{array}$ & 0.91 & 0.89 \\
\hline & & $\begin{array}{l}1 \text { and Non-1 } \\
\text { Range }\end{array}$ & 292 & $\begin{array}{l}1.03 \pm 0.20 \\
0.40-1.88\end{array}$ & $\begin{array}{l}1.04 \pm 0.20 \\
0.43-2.38\end{array}$ & $\begin{array}{l}1.02 \pm 0.19 \\
0.43-2.20\end{array}$ & 0.85 & 0.85 \\
\hline
\end{tabular}

1, 2, 3, 4 and 5. See Table I for these footnotes.

-On cortisol therapy.

${ }^{7}$ After gluten-free diet.

${ }^{8}$ Data on B.B. omitted from population data.

first and non-first solutions are given. Standard deviations and ranges for the population are also given. The means for polyethylene glycol, P.R.C., and phenol red-560 agree closely, and polyethylene glycol, P.R.C., and phenol red-560 correlate closely. Correlation of polyethylene glycol with P.R.C. is probably slightly better than with phenol red-560, at least in first solutions.

The same data for patients with malabsorption are compared in Table II. The means for P.E.G., P.R.C., and phenol red-560 for individuals and groups usually agree fairly well, although not as closely as in the normal subjects (Table I). The population range of data for phenol red extends to higher values than for polyethylene glycol. Polyethylene glycol and P.R.C. correlate more closely than polethy- lene glycol and phenol red-560. In general, data for P.E.G. and phenol red correlate fairly well but not as closely as in the normal subjects. Data on B.B. are not included in population statistics because P.R.C. is about $15 \%$ higher than polyethylene glycol.

Data on urinary phenol red excretion of patient B.B. are in Table III. The first urine specimen, collected about two hours after infusion, usually contained only about 1 to $2 \%$ of the retained phenol red (phenol red infused - phenol red recovered in samples) at most. The second specimen, collected several hours later, usually contained the largest amount, with a progressive decline in subsequent specimens. Total recovery in 18 hours averaged only $5.7 \%$ of phenol red retained. There was no cor- 
TABLE III

RECOVERY OF PERFUSED PHENOL RED

(P.R.) IN URINE IN A PATIENT WITH NON-TROPICAL SPRUE

Perfiusion Site, Distance From Nares, $(\mathrm{cm}$.)

P.R. Recovery ${ }^{1}$

$\%$ in 1st Urine Collection Total P.R. Recovery
Specimen Time, $(h r .)^{2}$ in $\%^{3}$

\begin{tabular}{rrrr}
\hline 63 & 0.5 & 1.9 & 4.6 \\
76 & 1.2 & 1.5 & 6.0 \\
80 & 0.2 & $1 \cdot 1$ & 7.3 \\
136 & 1.0 & 1.1 & 8.8 \\
152 & 0.7 & 1.4 & 3.5 \\
167 & 1.8 & 1.2 & 6.4 \\
204 & 1.8 & 1.6 & 11.8 \\
222 & 2.2 & 1.2 & 5.9 \\
281 & 1.7 & 1.3 & 3.8 \\
310 & 1.5 & 1.5 & 4.8 \\
332 & 1.8 & 1.6 & 3.7 \\
337 & 0.3 & 1.3 & 3.8 \\
346 & 0.6 & 0.9 & 8.3 \\
367 & 1.7 & 1.4 & 5.0 \\
369 & 0.2 & 1.3 & 1.8
\end{tabular}

'Recovery is expressed as percent of retained P.R. \% Recovery 100 [P.R. in urine/(infused P.R. - P.R. in samples)] ${ }^{2}$ Collection time of 1 st urine specimen voided after P.R. infusion.

${ }^{3}$ Recovery during the $18 \mathrm{hr}$. period following infusion.

relation between phenol red excretion and perfusion site.

Analysis of numerous urine specimens from normal subjects and patients after perfusion failed to demonstrate polyethylene glycol.

\section{DISCUSSION}

Polyethylene glycol and phenol red are examples of molecules that are poorly absorbed, but for very different reasons. Polyethylene glycol is a hydrophilic-lipophilic polymer composed of a population of elongated molecules of high molecular weight. The molecules are probably sufficiently lipophilic to be absorbed (Shaffer, Critchfield, and Nair, 1950), but their passage through the cell membrane is limited by their size and shape (Shaffer and Critchfield, 1947). Phenol red is a triphenylmethane dye and the molecule is too large to pass through pores in the intestinal membrane. Since phenol red is a strong electrolyte and is lipid insoluble and hydrophilic at the $p \mathrm{H}$ of the small bowel, it is slowly absorbed. These diverse molecules are measured by widely differing methods: P.E.G. turbidimetrically, phenol red colorimetrically. It seemed of interest to compare indicator data on two such widely differing substances, as some insight into the validity of using non-absorbed indicators, and the reproducibility and reliability of indicator measurements might thereby be gained.

In general the data on normal subjects (Table I) support the validity of using indicators in absorption studies. The c'ose agreement between means and the high correlations show that essentially the same findings would be obtained from the use of either indicator. In patients with intestinal malabsorption, although the agreement of mean data is almost as close (with the exception of patient B.B.), correlation between the two indicators is not as high. This suggests that, in addition to the usual technical difficulties associated with absorption measurements in such patients, there are also difficulties with indicators.

The following considerations are important in the interpretation of discrepancies between polyethylene glycol and phenol red data: 1 analytical problems posed by interference from coloured samples in phenol red analysis, and 2, absorption of indicator.

1 coloured SAMPLes When samples are coloured, the apparent $C_{F}$ is raised, and when phenol red-560 is calculated the ratio $C_{I} / C_{F}$ is lowered. Samples from perfusion often have a yellow colour acquired from intestinal contents. The samples show an absorption spectrum which is nearly linear over the range 520-500 $\mathrm{m} \mu$, with an upward slope toward shorter wavelengths. Measurements at three wavelengths correct for errors from the presence of such colours in samples (Allen, 1950). Such interference would give P.R.C. ratios that are higher than phenol red560 ratios. This is generally true for both normal subjects and patients (Tables I and II). Assuming that the data for polyethylene glycol do not suffer from this source of interference because polyethylene glycol is analysed in a colourless filtrate, the finding that P.E.G. correlates better with P.R.C. than phenol red-560 is also in accord with more interference with phenol red-560 than P.R.C. Examination of the data, however, shows that no great advantage is usually gained by the additional measurements required to obtain phenol red ratio corrected.

2 INDICATOR ABSORPTION A considerable body of evidence supports the virtual non-absorption of polyethylene glycol (Shaffer and Critchfield, 1947; Sperber and Ekman, 1953; Jacobson et al., 1963). There is general agreement that phenol red is absorbed, but estimates of rate vary (Reynell and Spray, 1956; Schanker et al., 1958; Pearson, 1958; Wiggins and Dawson, 1961; Levitan, Bikerman, Burrows, and Ingelfinger, 1963). Phenol red absorption, by lowering $\mathrm{C}_{\mathrm{F}}$, would raise both P.R.C. and phenol red-560 ratios. Thus, assuming P.E.G. to be unabsorbed, the extent to which phenol red ratios are greater than P.E.G. ratios gives an index of phenol red absorption. Regardless of indicator absorption, phenol red-560 values would be affected by colour in samples. The greater the amount of colour the lower phenol red-560 relative to P.R.C. 
In patient B.B. both P.R.C. $(1 \cdot 18)$ and phenol red$560(1.08)$ are greater than P.E.G. (1.02) (Table II), which is consistent with phenol red absorption. The P.R.C. was greater than phenol red-560, as expected in the presence of coloured samples. Indicator absorption was studied by analysing urine for phenol red and polyethylene glycol, which was not detected. Phenol red was always found, but total excretion in 18 hours averaged only $5 \%$ of retained phenol red (Table III). Usually less than $2 \%$ was excreted in the first two hours. The largest portion of phenol red was excreted in the second specimen which was collected several hours subsequently. Using this index of phenol red absorption, the magnitude of the discrepancy between P.E.G. and phenol red data in B.B. cannot be explained by phenol red absorption. The general tendency for slightly higher values for P.R.C. than for P.E.G. in other subjects (Table I and II) can be explained by the slow rate of phenol red absorption.

These studies support the use of P.E.G. and phenol red as indicators for small intestinal perfusion studies. More consistent data with the two indicators are obtained in normal subjects than in patients with malabsorption. In perfusion studies the stomach is bypassed and a short segment of bowel is perfused under steady-state conditions. The total time between entry and sampling when the indicator is in contact with mucosa is relatively short. These experimental conditions probably account for some apparent discrepancies with previous findings with phenol red. Thus, gastric absorption at the low $p \mathrm{H}$ of the stomach converting phenol red to the unionized form, as well as longer mucosal contact time, are involved in a study reporting high urinary phenol red excretion (Levitan et al., 1963). We also observed phenol red absorption but the rate is slow under the conditions of our studies. Our data agree with the many reports that polyethylene glycol is not appreciably absorbed. If absorbed into the blood, circulating polyethylene glycol would be excreted in the urine (Shaffer, Critchfield, and Carpenter, 1948), and we have been unable to demonstrate this either in normal subjects or in patients with malabsorption. Polyethylene glycol is the preferred indicator because it is less absorbed and apparently not influenced by $p \mathrm{H}$.

\section{SUMMARY}

Polyethylene glycol (P.E.G.) and phenol red were compared as non-absorbed indicators for intestinal absorption studies in man by using them together in the same solution. With 785 samples from normal subjects, data for P.E.G. and phenol red had a correlation coefficient of 0.94 and the mean data from the two indicators agreed within $2 \%$. In 292 samples from patients with malabsorption, the means agreed within $1 \%$, but the correlation coefficient was $0 \cdot 85$. Both indicators are suitable for studies in normal subjects, although P.E.G. is preferred. Discrepancies between the indicators in patients with malabsorption are not explicable solely by phenol red absorption or interference with phenol red analysis by colour in the samples.

\section{REFERENCES}

Allen, W. M. (1950). A simple method for analyzing complicated absorption curves, of use in the colorimetric determination of urinary steroids. J. clin. Endocr., 10, 71-83.

Borgström,, B., Dahlquist, A., and Lundh, G. (1962). On the site of absorption of fat from the human small intestine. Gut, 3, 315317.

Hydén, S. (1955). A turbidimetric method for the determination of higher polyethylene glycols in biological materials. LantbrHögsk. Ann., 22, 139-145.

Jacobson, E. D., Bondy, D. C., Broitman, S. A., and Fordtran, J. S. (1963). Validity of polyethylene glycol in estimating intestinal water volume. Gastroenterology, 44, 761-767.

Levitan, R., Bikerman, V., Burrows, B. A., and Ingelfinger, F. J. (1963). Rectosigmoidal absorption of phenolsulphonphthalein (PSP), sulfisoxazole diethanolamine (Gantrisin), ard radioiodine $\left(I^{131}\right)$ in normal subjects and patients with idiopathic ulcerative colitis. J. Lab. clin. Med., 62, 639-645.

Lundh, G. (1958). Intestinal digestion and absorption after gastrectomy. Acta chir. scand., suppl. 231.

Pearson, J. W. (1958). Continuous perfusion and absorption in the jejunum of the dog. J. appl. Physiol., 13, 313-316.

Reynell, P. C., and Spray, G. H. (1956). The simultaneous measurement of absorption and transit in the gastro-intestinal tract of the rat. J. Physiol. (Lond.), 131, 452-462.

Schanker, L. S., Tocco, D. J., Brodie, B. B., and Hogben, C. A. M. (1958). Absorption of drugs from the rat small intestine. $J$. Pharm. exp. Ther., 123, 81-88.

Schedl, H. P., and Clifton, J. A. (1961). Small intestinal absorption of steroids. Gastroenterology, 41, 491-499.

- - (1963). Cortisol absorption in man. Ibid., 44, 134-145.

Shaffer, C. B., and Critchfield, F. H. (1947). The absorption and excretion of the solid polyethylene glycols ('Carbowax' compounds). J. Amer. pharm. Ass., sci. Ed., 36, 152-157.

,-- , and Carpenter, C. P. (1948). Renal excretion and volume distribution of some polyethylene glycols in the dog. Amer. $J$. Physiol., 152, 93-99.

$\longrightarrow,-\ldots$, and Nair, J. H., III (1950). The absorption and excretion of a liquid polyethylene glycol. J. Amer. pharm. Ass., sci. Ed., 39, 340-344.

Sperber, I., and Ekman, J. (1953). The use of polyethylene glycol as a reference substance in the study of ruminant digestion. Lantbr-Högsk. Ann., 20, 337-344.

Wiggins, H. S., and Dawson, A. M. (1961). An evaluation of unabsorbable markers in the study of fat absorption. Gut, 2, 373-376. 